\section{Communication Difficulties between Different Liturgical-Musical Paradigms:}

An Orthodox Perspective

\author{
VASILE GRĂJDIAN*
}

\begin{abstract}
Contemporary ecumenical efforts face considerable difficulties due to differences of liturgical and musical paradigm between different confessions. Therefore, in opposition to a vision that is of secular inspiration and often eclectically and syncretically built in ecumenical manifestation, the Orthodox Church presents a traditional liturgical-musical perspective, a cosmic and soteriological typology, whose cyclical arrangement and liturgical hymns share a sacramental connection with divine revelation.
\end{abstract}

Keywords: ecumenical liturgical music Orthodox Church

The account presented in the following pages is mostly the result of the activities that I have pursued over the past decades as, for example, Professor of Orthodox Church Music and Ritual at the Faculty of Orthodox Theology in Sibiu, ${ }^{1}$ and Artistic Consultant/Musical secretary of the State Philharmonic, Sibiu. ${ }^{2}$ I have also been an organiser/participant with musical responsibilities within initiatives/activities and ecumenical undertakings such as the Third European Ecumenical Meeting in Sibiu ${ }^{3}$, and also within the International Association Fondacio-Chretiens pour le Monde ${ }^{4}$ or the Reconciliation in South-EastEurope Foundation in Sibiu ${ }^{5}$ and others. These activities have also included a mass-media component, by which I mean the written press and other types of publication (books), radio, television, and the internet.

\section{Ecumenical attitudes in the liturgical-musical field}

For those who share an interest in music within the church, what immediately emerges as obvious in the cultural (lay/secular) and ecumenical areas

\footnotetext{
*Vasile Grăjdian, Dr., Professor of Orthodox Church Music and Ritual at the Faculty of Orthodox Theology "Sf. Andrei Şaguna”, Lucian Blaga University, Sibiu. Address: Lucian Blaga University, Str. Mitropoliei nr. 20, Sibiu, Romania; e-mail: vasilegrajdian@gmail.com

1 http://teologie.ulbsibiu.ro/cadre-didactice/, viewed 10.05.2015.

2 http://www.filarmonicasibiu.ro/ro/administratia.htm, viewed 10.05.2015.

3 Luca M. Negro, Sabine Udodesku (eds.), Songs, Gesange, Chants, Canti, (The Songbook for the) 3rd European Ecumenical Meeting, Sibiu, Romania, 4-9 September 2007, p. III.

4 http://www.fondacio.org/spip.php?article78, viewed 10.05.2015.

5 http://www.healingofmemories.ro/ofices-and-staff, viewed 10.05.2015.
} 
is the need to accommodate one's actions to the existing and, at least for the present, acknowledged differences between different cultural/religious models/ views and even paradigms. More plainly and directly speaking, what is appropriate in the Church is not necessarily appropriate on the show/concert stage. The reverse is also valid; namely, what is appropriate on the stage is not necessarily also appropriate in the Church, except for some relatively rare cases.

On the other hand, ecumenical situations present a somewhat intermediate scenario in which, in default of a common altar, an ad-hoc stage gathers together the "front-rank" of the participating religious systems, oftentimes next to or alternating with musical participants while "the wide public" is made up of various believers of the respective confessions. An ecumenical manifestation also uses a series of symbols or symbolic actions relatively common to Christian confessions, such as the cross, light/candles, processions etc, whose effect is to get all participants as actively involved as possible. In this sense and in a rather eclectic manner there is an effort in the musical area as well to include chants/hymns/musical works which are representative or emblematic of different religions and as much as possible known by as many as possible from among those present. Inevitably, the greatest "success" is almost always seen on the side of simple melodic formulas, which are repetitive and easily learned or kept in mind by most of the participants and which either come from a common history (such as the Kyrie eleison) or are among the songs widespread in younger ecumenical initiatives (such as the chants of the Taizé community). ${ }^{6}$

During preparation periods or as result of important ecumenical events Ecumenical chant books have also been issued: smaller or more comprehensive, real anthologies made up of selected chants from different confessions and considered as appropriate for ecumenical meetings. ${ }^{7}$

One must state from the very beginning that traditional churches, especially those from before the Protestant reform, have often (if not always) held themselves back with regard to contemporary ecumenical manifestations/ meetings, because generally the Church, in the whole of its historical existence has expressed a pastoral-missionary reality which is at least equivalent to ecumenism and which is called either catholic (Church), or even ecumenical (Patriarchy) or synodal (Church) - a reality which cannot be given up and which cannot be so easily replaced. The difference in services that are defin-

\footnotetext{
6 http://www.taize.fr/en_article10308.html, viewed 17.05.2015.

7 For example, the ecumenical book published by IAH (International Fellowship for Research in Hymnology) in several languages: Markus Jenny, Andreas Marti, et al. (eds.) Unisono, Graz 1997.
} 
ing for the ecclesial being and identity was therefore greater in the liturgical sphere, to the point that the respective ecumenical gatherings may not be considered true liturgical synaxes, but only, at the most, para-liturgical events.

The problem is not new and concerns the different attitude towards Tradition of the old churches, on the one side, and the newer (historically) confessions, on the other. If the former show an extremely special concern for preserving the Holy Tradition, which is inspired by the Holy Ghost and proven by a bimillennial history - and into which all particular traditions fall, including (or especially) those of liturgical life - Protestant and especially neo-Protestant confessions seem to organise new traditions in a more voluntary and hasty manner, depending on the new realities of the world and of history. The latter is definitely a more modern view or mentality and ecumenical manifestations seem to be in the same vein. Therefore, for the gathering together of all believers/Christians, one may even deem appropriate an eclectic collection of liturgical and musical traditions which have been, actually, differently developed in every single confession during the course of history.

To sum up, the ecumenical state of affairs may be depicted as similar to organising a museum, in which, for example, products/artefacts from various past cultures/civilisations are gathered together, artefacts which, once taken apart from their context, cannot render anything but a pale image of the (living) life of any of the respective cultures or civilisations. Moreover, "the museum" is also intended to be an ecumenical, religious "super-market" in which every believer, from any confession, should find the (liturgical-musical) "soul nourishment" that he or she is used to, even if he or she is placed in an entirely new situation. It is a globalising image with strong secular tones, which seems to go beyond even the ecumenical dimension and which can at times give a worrisome shudder , at the very least, to the believer from a traditional Church.

\section{Musical-liturgical life in the Tradition of the Orthodox Church}

The view or the traditional paradigm of the Church regarding the catholicity /ecumenicity/synodicity of its being and mission is rather dissimilar, if not altogether different. I will try to depict this situation by referring to the musical/liturgical reality of the Orthodox Church. Even if it may appear to the "(post)modernist" eye as locked/trapped in a traditionalist stillness, the Orthodox Church is in fact completely full of life, the life of the Spirit (al-

\footnotetext{
8 In the meaning of "... tradition, which is a genetic vision of the present, a present conditioned by its understanding of its roots", to Robert F. Taft, S.J., Beyond East and West: Problems in Liturgical Understanding, Second revised and Enlarged Edition, Rome 1997, p. 191-192.
} 
though, it is true that this is sometimes hidden from a superficial perspective) and, at the same time, as open as possible to all created/creatures of God.

From an obvious, visible perspective, there are in the Orthodox Church as well liturgical manifestations, with a musical feature that is almost continuously present. There are also books (service books, chant books) in a manner that is somehow similar to ecumenical (chant and program) manifestations and books. But the similarities stop here, at the visible, obvious level. From here onwards one must probably also try to understand the difficulties in communicating between the traditional paradigm of the Church (especially the Orthodox Church) and the ecumenical model or, in other words, the difficulty of conforming a potential orthodoxy to the model of modern ecumenical movements. That is because the visual aspects of the manifestations and books of the Orthodox Church correspond to completely different sources, which are unseen and spiritual.

First of all, the whole of the music in the Orthodox Church is inseparably linked to the liturgical reality. All Orthodox chants are liturgical or for the liturgy. The Orthodox chant/hymnography is liturgical" otherwise it is not "Orthodox" anymore, namely "true-minded". Furthermore, the place of the service is in the Church. That is the reason why the liturgical Orthodox chant is also always called church chant, on the basis of the inseparable connection between the being of the Church and liturgical life - the Church itself coming into being through its services. ${ }^{10}$ Therefore, Orthodox church/liturgical music/chant, when taken out of its church and liturgical context and placed in a cultural/artistic context for a secular show/concert or ecumenical manifestation begins to lose its identity. This occurs even at a missionary level, because the mission itself presupposes an already existing liturgical reality and is on the verge of natural (and providential, not just humanly "mixed") expansion.

Parenthetically, Orthodox liturgical music is chant and chant alone (vocal music by definition) because the word must be permanently present in the liturgical hymn, as icon of the Word of God. The only being in this world (after God, at His Incarnation in the Person of the Son ${ }^{11}$ and angels ${ }^{12}$ ) who

9 Egon Wellesz, A History of Byzantine Music and Hymnography, II. Ed., Oxford 1961, p. 26: „it was indispensable to place Byzantine hymnography in its liturgical environment”.

10 Evangelos Theodorou, "La phénoménologie des relations entre L'Eglise et la liturgie" in : Eglise dans la liturgie, (Conférences Saint-Serge, XXVI-e semaine d'études liturgiques, Paris, 1979), Rome 1980, p. 282; Alexander Schmemann, Introduction to Liturgical Theology, $3^{\text {rd }}$ Ed., New York 1986, p. 24.

11 Mk. 14: 26, Mt. 26: 30.

12 Is. 6: 3; Lk. 2: 14. 
is able to sing with meaningful/spiritual words is the human being, who was created "in the image, in the likeness" of God (Gen. 1, 26).

\section{The revealed perspective of the musical-liturgical life in the Orthodox Church}

The organization of the religious system (with its respective specificity/ ritual) and, implicitly, of its chants actually refers directly to the Revelation, to the seen/natural Revelation and to the unseen/supernatural one. The religion and its chants are therefore organized according to liturgical cycles ${ }^{13}$. They are not arbitrary, but connected to the divine Economy of Creation and Redemption. As regards the Creation, a visible, observable and discernable aspect is the succession of the light of the day and the darkness of the night, a reality to which a first (liturgical) cycle, the daily one, corresponds in the area of liturgical life. The reality of the creation of the day is noted in the very first chapter of the Holy Scripture, when 'God called the light 'day,' and the darkness he called 'night.' And there was evening, and there was morning - the first day." (Gen. 1: 5). One may already notice in this sequence of the Scripture that, although "day" refers to the entire cycle of the day, with its evening and morning, "day" names, first of all, the light. But in the present astronomic situation of Creation, (after the fall into temptation of the forefathers of humankind - Gen. 3), we name and include the night and its darkness in the day cycle as well, although we still use the name "day" in our common speech especially for the light part of a whole day. These observations will play their role later as well, when we will talk about the "eveningless day of the Kingdom" of God, ${ }^{14}$ and its consequences for the liturgical and musical order of the Church.

For the time being, one can observe that the day is liturgically shaped, albeit differently, in the service books of the Orthodox Church - in Hieratikon, Horologion, Triodion, Pentecostarion, Octoechos, and Menaion ${ }^{15}$ - and

13 Christian Hannick, "Le texte de l'Oktoechos, in Dimanche, office selon les huit tons - Oktoechos" in: La prière des Églises de rite byzantin, 3, Chevetogne, 1972, p. 41: "l'ordonnance actuelle des livres liturgiques byzantins résulte de deux tendances consécutives: l'ordre des hymnes autrefois fixé d'après leur genre hymnographique s'est peu à peu muté en un agencement correspondant au déroulement des différents cycles et moments liturgiques." 14 Liturghier, Bucharest 1987, p. 167: „Dă-ne nouă să ne împărtăşim cu Tine, mai cu adevărat, în ziua cea neînserată a Împărăţiei Tale.” („Bestow upon us, that we be in communion with You, in the eveningless day of Your Kingdom”).

15 The service books and the collections of hymns consulted for this occasion are part of the numerous and repeated issues of the Biblical and Mission Institute of Romanian Orthodox Church Publishing House; besides the already mentioned Liturghierul: Horologion, $2^{\text {nd }}$ Ed., Bucharest, 1973; Octoih mare, 6 ${ }^{\text {th }}$ Ed., Bucharest 1975; Triod, $8^{\text {th }}$ Ed., Bucharest 1986; Penticostar, $7^{\text {th }}$ Ed., Bucharest 1988; Menaion on: January, $5^{\text {th }}$ Ed., 
various moments of the day are marked by special services, such as the Hours $(1,3,6,9)$, Vespers, Compline, Midnight Office, and Matins. Two of these services draw special attention due to the out of the ordinary proportion of chants/hymns in their overall duration. The greatest percentage of the Orthodox chants/hymnography (of Byzantine origin) is concentrated in the evening service (Vespers) and the morning service (Matins) in the collections Octoechos, Triodion, Pentekostarion, and the collection of the 12 Menaion. The traditional order of daily services begins with the evening service (the Ninth Hour and the Vespers), ${ }^{16}$ following the word of the Scripture, where "there was evening, and there was morning - the first day" (Gen. 1:5). Only in the Horologion ("the book of daily hours") does the order of daily services begin with the morning Prayers. ${ }^{17}$

The liturgical fulfilment of the day is accomplished by the Holy Litur$g y$, the service structured towards the noon (and, of course, the peak of the light) of the day. This is the service within which the Holy Sacrament of the Eucharist is performed and which is, at the same time, a perfect sacramental recapitulation (anamnesis) of the entire Holy History of Salvation.

But the cosmic framing of the services and, implicitly, of orthodox liturgical chants does not limit itself to the (astronomic) reality of the day as alternation of light and darkness, but it also acknowledges the existence of certain "lights" about whose creation the Holy Scripture tells us at the beginning that "God said, 'Let there be lights (also linked with the light of the day and of the night - n. n.) in the vault of the sky to give light on the earth. ${ }^{18}$, And it was so. God made two great lights - the greater light to govern the day and the lesser light to govern the night. He also made the stars. God set them in the vault of the sky to give light on the earth, to govern the day and the night, and to separate light from darkness. And God saw that it was good" (Gen. 1: 14-18).

Bucharest 1975; February, $5^{\text {th }}$ Ed., Bucharest 1976; March, $5^{\text {th }}$ Ed., Bucharest 1977; April, $5^{\text {th }}$ Ed., Bucharest 1977; May, $5^{\text {th }}$ Ed., Bucharest 1978; June, $4^{\text {th }}$ Ed., Bucharest 1972; July, $5^{\text {th }}$ Ed., Bucharest 1984; August, $4^{\text {th }}$ Ed., Bucharest 1974; September, ${ }^{\text {th }}$ Ed., Bucharest 1984; October, $5^{\text {th }}$ Ed., Bucharest 1983; November, $5^{\text {th }}$ Ed., Bucharest 1983; December, $6^{\text {th }}$ Ed., Bucharest 1991.

16 Liturghier, p. 21; Tipic bisericesc, Bucharest 1976, p. 18.

17 Horologion, p. 7.

18 Let us observe that, for symbolic implications, we refer here to "the lights in the vault of the sky (italics mine)" (Gen.1:14) and not to (any vault) of the earth, to shed light... Therefore it is not the earthly things (be they scientific) that shed light upon the heavenly things, but the established divine order is for the heavenly things to shed light upon the earthly things „and to separate light from darkness” (Gen. 1:18), which corresponds at a spiritual level to a certain (spiritual) discernment with regards to created/existent things... 
Thus a first obvious fact, easily noticeable, is the association of the cycle of the day and of the night with the ("daily") alternation of the sun's presence and movement in the vault of the sky, and, respectively, of the moon, - a cycle which has as equivalent, in the Orthodox, religion, the daily Orthodox cycle, with the chants organized accordingly.

But there are other "visible", obvious facts, subtler and more difficult to discern (but, nevertheless, still observable) as they presuppose paralleling the observations of the movement of the moon and/or of the sun during several days, and allow us to notice other, greater, astronomical cycles. As regards the moon, "the lesser light to govern the night" (Gen. 1: 16), its observable phases during approximately 29.5 days (new moon/full moon/new moon) determine more or less the month of the calendar, which corresponds to the menaion cycle in the Orthodox liturgical perspective, with the corresponding service book called Menaion (Menaion in the Greek language - "the book of the moon" or the "monthly" book in translation) which is comprised especially of hymns for the Vespers and Matins for each of the days of the month.

Another cyclicity, stretched over an even greater period, which is at its turn astronomically noticeable, regards the sun, "the greater light" (Gen. 1, 16) whose height of movement on the vault of the sky varies gradually, from a minimum (winter solstice) to a maximum of its height (summer solstice) when the respective, apparent height is measured at noon. The approximately 365 days of repeated return to the same initially observed solstice (be it winter or summer solstice) define the solar year, which corresponds to the calendar year (with a slight approximation which is periodically corrected through the leap year), and respectively corresponding to the liturgical church year, which is comprised of 12 months, and to which the cycle of the 12 Menaion corresponds, in liturgical perspective, with a hymn book for every month.

The annual movement/change of the position of the stars corresponds to the annual movement of the sun that can be observed in the daytime. These are grouped in constellations (and form thus the zodiac) which have been arranged in their turn by the Creator of all in such a way that "Let them mark the seasons, the days and the years (italics mine), and serve as lights in the dome of the sky, to illuminate the earth" (Gen. 1: 14-15).

But the liturgical life of the Orthodox Church, as rich in chants of great diversity as in hymnographic forms (Troparions, Kontakions, Canons), does not merely correspond to astronomical cycles. The Tradition of the Christian Church, following older models at times, has associated (by a profound symbolic logic) to special periods and even to each of the days of the liturgical year (which begins on September 1) special moments or saint persons from the History of the Redemption of humankind, according to the way in which 
their memory was preserved in the Old and the New Testament or in the History of the Christian church. Greater or lesser feasts (the great ones begin with the feast of the Birth of the Blessed Virgin Mary in the eighth day of the month of September, the first month of the church year), going through fast days and periods that are fixed dates, all the way up to the Assumption of Virgin Mary, in the middle of the month of August, and the Enshrinement of the Cincture of the Mother of God, that also closes the church year in this month, all support the participation of Orthodox Christians in the entire holy history of Redemption ${ }^{19}$. This also entails musical-liturgical implications, as a great richness of specially intended chants are dedicated to all moments and holy persons which are celebrated - indeed feasted - as festivals for each day.

Generally speaking, in present ecumenical manifestations where could one find this natural cosmic and, at the same time, church-historical view, this liturgical (and, implicitly, musical) awareness of personal-communitarian participation and framing within the divine order of Creation and Redemption as a testimony of permanent faith?

\section{The soteriological and eschatological dimension of Orthodox musical- liturgical life}

If the liturgical cycles that were presented above correspond to "visible" obvious astronomical phenomena, there is another series of cycles within the customs of the Orthodox Church which point to a less "visible' or "unseen" dimension: the part of divine supernatural Revelation, which is not accessible through bodily senses, but only through the spiritual "sight" that is faith. It is faith "that is the realization of what is hoped for and evidence of things not seen.” (Heb. 11: 1)

In this respect we could ask ourselves, what is the (calendar and liturgical) obvious characteristic of the weekly, i.e., seven-day cycle, because, humanly speaking (which may be practical and useful), other (lesser or greater) groupings of days had occurred in the pre-Christian history of the world, ${ }^{20}$ eventually by twos, fives or even tens ("decades", since we count decimally...)? As regards the week, it is not about an observable astronomical fact, but about a direct connection to divine Revelation itself, as it is preserved in the Holy Scripture, where even in the first two chapters is described to us how in the seven days of

19 So, the liturgical year "... gives us the energy to become the fullness of ourselves", see: Joan Chittister, Tickle Phyllis, "The Liturgical Year. The Spiraling Adventure of the Spiritual Life" in: The Ancient Practices Series, Thomas Nelson Inc. 2009, p. 59.

20 Ene Braniște, Liturgica generală - cu noţiuni de artă bisericească, arhitectură și pictură creștină, $2^{\text {nd }}$ Ed., Bucharest 1993, p. 130. 
Creation "the heavens and the earth and all their array were completed. On the seventh day God completed the work he had been doing; he rested on the seventh day from all the work he had undertaken.” (Gen. 2: 1-2).

Used by a great part of the world and mostly by Christians, the weekly liturgical cycle, which starts on Sundays (actually, with the evening service on Sunday's eve) and ends the next Saturday, through its liturgical usage itself forms a testimony of faith in God, Who is the "Maker of all seen and unseen." ${ }^{21}$ To each of the days of the week the Orthodox Church has associated a special meaning and feast which are illustrated in the corresponding liturgical chants/hymns: Sunday is the weekly feast of the Resurrection of the Lord, Monday is dedicated to the Holy Angels, Tuesday is devoted to the Holy Prophets and especially to the Holy Prophet, Forerunner and Baptist John, Wednesday and Friday are devoted to the Holy Cross and Holy Passions of the Redeemer, Thursday is devoted to the Holy Apostles and Saint Hierarch Nicholas, and Saturday is devoted to the commemoration of all those departed (to the dead) and, primarily, of the Holy Confessors and Martyrs. ${ }^{22}$

As the beginning of the church year (September 1) may fall on any of the days of the week, according to the civil calendar, which day could be the yearly week beginning? In this respect, the day of Sunday displays special importance because, as day of the Resurrection of the Lord $^{23}$, the most important event in the history of Redemption ${ }^{24}$, it is this day that also determines the beginning of the counting of the number for every Sunday (and, implicitly, of every week), in their yearly sequence. The Sunday of Holy Easter has an astronomical determination as well (regarding the position of the sun and the moon, insofar as it is the first Sunday after the first full moon following the spring equinox). But, much more than this, it is the first of all the Sundays, the Day of the Resurrection of the Lord, the Day that God Himself assigned in the beginning to be the Beginning of all and, at the "fullness at time" (Gal. 4: 4) to be the beginning of the Redemption for everybody.

\section{Liturghier, p. 146.}

22 E. Braniște, Liturgica generală, p. 131.

23 Adolf Adam, The Liturgical Year: Its History and Its Meaning After the Reform of the Liturgy, Collegeville 1992, p. 36: "The New Testaments does, however, present us with the first component of a liturgical year that will develop only very gradually. This component is the celebration of Sunday, the first day of the Jewish week. This was the day of the Lord's resurrection, as all the evangelists agree".

24 Thomas J. Talley, "Liturgical Time in the Ancient Church: The State of Research" in: E. Johnson Maxwell (ed.), Between Memory and Hope: Readings on the Liturgical Year, Collegeville 2000, p. 25: "Let us at the outset take all available comfort from what seems still to be a matter of general agreement: Pasha is the earliest annual festival of the Christian Church." 
One must emphasize that the symbolic meaning of the Day of Sunday goes far beyond any determination, astronomical or otherwise. As the Day of the Resurrection of the Lord (of Holy Easter) it is the beginning of the Bright Week which is actually only the outpouring into the world of the same and only Day of Resurrection. It is called "bright" because of the countenance of the days of Heaven, where only "Evening came, and morning followed" (Gen. 1: 5), without night or other darkness. Thus the Sunday of the Resurrection is not only the first day of the week, but the one day, the first and the eighth day of the week, the eternal day, and the "eveningless day of the Kingdom" 25 of God, in which we are being called to partake. In this re-established order of Creation the (astronomical) "lights" are no longer considered the factors to determine the form of the church praises. On the contrary, the form of the church praises is determined by the very cycle of the eight tones of the chants (of the Octoechos), according to the symbolic number of the eschaton (eight). The row of tones begins on the Day of Holy Easter itself and the tones follow one after the other in each of the days of the Bright Week, and, afterwards, one every week.

The succession of one tone a day in the Bright week and, afterwards, one tone a week, seems to indicate a certain symbolic equivalence between the days and the weeks after the Resurrection. Thus, if the first week after the Resurrection/the Bright Week - is (like) one single "eveningless day", then the "week of weeks of the seven weeks (like "bright Resurrection day-weeks") from Holy Easter to Pentecost is one and the same as the eternal Day of the Resurrection Sunday.

Saint Basil the Great describes clearly this liturgical and sacramental reality: "we stand for prayer on the day of the Resurrection to remind ourselves of the graces we have been given: not only because we have been raised with Christ (...) but also because Sunday seems to be an image of the age to come. Notice that although Sunday is the beginning of days, Moses does not call it the first day, but one day: 'And there was evening and there was morning, one day' since this day would recur many times. Therefore 'one' and 'eight' are the same, and the 'one' day really refers both to itself and to the 'eighth' day. This day foreshadows the state which is to follow the present age: a day without sunset, nightfall or successor, an age which does not grow old or come to an end. (...) the entire season of the Pentecost is likewise a reminder of the resurrection we expect in the age to come. If we count that one day, the first of days, and then multiply it seven times seven, we will have completed the seven weeks of the holy Pentecost, and the

25 Liturghier, p. 167. 
season ends on the same day it began (Sunday) after fifty days have elapsed. Therefore this season is an image of eternity, since it begins and ends at the same point, like a circle." ${ }^{26}$

After the eight week long period (with the same number as that of the tones of the Octoechos) of the Pentecost book (from Holy Easter to the end of the week after the Feast of Pentecost) when the church counting of Sundays and weeks restarts, the period of the Octoechos itself follows, in which the row of church tones of liturgical chants is repeated again and again every eighth week, one tone per week. The framework of their tones and chants is also preserved in the time of the Triodion (with Lent and Holy Week), which starts ten weeks before Holy Easter of the next year and which thus completes the (yearly) Easter Cycle. The chants of this cycle, the Resurrection Chants, which are directly under the light of the Holy Resurrection of the Redeemer during Pentecost, spread then the light of the Resurrection on the entire duration of the church year, because the Chants of the Octoechos, as we are let known by the very title of the book in its entirety, are "The Chants of the Resurrection for all the days of the week in the eight church tones." 27

In the church Ritual of the Orthodox Church, the combination of the chants of the two cycles, the Menaion (with a fixed date) and Easter (with a variable date) seems to reveal to us something about the illumination of the Menaion cycle for the "Creation" ("seen" in a more earthly, astronomical manner) by the Easter/Resurrection cycle, a cycle which is revealed par excellence at a spiritual and sacramental level.

\section{Conclusions}

In view of the aforementioned, it is difficult for the Orthodox believer to give up a liturgical life in the completeness of the permanent actualization of the divine Revelation (cosmic and soteriologic at the same time) through the mediation of liturgical chants of Byzantine origin and of revered church tradition, a completeness which goes far beyond the historical immanence of individual or group "initiatives" (which are at times mere "ambitions").

Any kind of renunciation in favour of other (para-)liturgical or "ecclesial" arrangements is even more difficult, as it seems much more difficult (if not impossible) in (or for) these latter arrangements to achieve a deep and authentic spiritual justification, namely as regards the true and hidden work of the Grace of the Holy Spirit.

\footnotetext{
26 Saint Basil, On the Holy Spirit, translated by David Anderson, Crestwood 1980, p. 101.

27 OCTOIH MARE care cuprinde cântările Învierii pentru toate zilele săptămânii pe cele opt glasuri bisericești..., $6^{\text {th }}$ Ed., Bucharest 1975.
} 
Nevertheless, in a somewhat mutual manner, liturgical hymns of Byzantine origin were translated throughout the centuries in each of the languages of the peoples in which Orthodox Christians lived and assumed the religious forms and the chants of the Orthodox Church as well, in such a way that this true musical-liturgical treasure might be offered to everyone, for Redemption. 